\title{
Seedling formation and field production of beetroot and lettuce in Aqui- dauana, Mato Grosso do Sul, Brazil
}

\author{
Paulo AM Leal ${ }^{1}$; Edilson Costa ${ }^{2 *}$; Jolimar A Schiavo² ${ }^{2}$ Alexander B Pegorare $^{2}$ \\ ${ }^{1}$ UNICAMP-FEAGRI, C. Postal 6011, 13083-970 Campinas-SP, Brasil; pamleal@ feagri.unicamp.br; ${ }^{2}$ UEMS, Unid. Universitária de \\ Aquidauana, C. Postal 25, 79200-000 Aquidauana-MS; *autor correspondente: mestrine@uems.br
}

\begin{abstract}
In horticulture, the proper use of containers and substrates for the production of seedlings are important factors that affect crop productivity in the field. This study aimed to evaluate the effect of different containers and substrates in the production of lettuce (Lactuca sativa, cv Veneranda) and beetroot (Beta vulgaris, cv Top Tall Early Wonder) seedlings in nursery with monofilament screen, $50 \%$ of shading, and the productivity of these species when transplanted to field plots. In protected cultivation, a completely randomized experimental design, in a $3 \times 3$ factorial scheme (three polystyrene trays, $\mathrm{R} 1=72, \mathrm{R} 2=128$ and $\mathrm{R} 3=200$ cells and three substrates, $\mathrm{S} 1=93 \%$ of soil $+7 \%$ of organic compost, $\mathrm{S} 2=86 \%$ of soil $+14 \%$ of organic compost and $\mathrm{S} 3=79 \%$ of soil $+21 \%$ of organic compost) was used, with 15 replications, where one plantlet was a replication. In the field, the nine treatments were evaluated in a completely randomized experimental design. The 72 cells tray with $7 \%$ commercial organic compost substrate promoted the best beetroot and lettuce seedlings. In the field, the plants from the 72 cell tray produced greater plants, independent of substrates type.
\end{abstract}

Keywords: Lactuca sativa, Beta vulgaris, trays, substrates, organic compost.

\section{RESUMO}

Formação de mudas e produção a campo de beterraba e alface em Aquidauana-MS

$\mathrm{Na}$ olericultura o uso adequado de recipientes e substratos para a produção de mudas são fatores importantes e que afetam a produtividade das culturas a campo. No presente trabalho objetivou-se avaliar, em viveiro de tela de monofilamento com $50 \%$ de sombreamento, o efeito de diferentes recipientes e substratos na produção de mudas de alface (Lactuca sativa, cv Veneranda) e beterraba (Beta vulgaris, cv Top Tall Early Wonder), bem como a produtividade dessas espécies quando transplantadas em canteiros a campo. No ambiente protegido utilizou-se o delineamento experimental inteiramente casualizado, em esquema fatorial $3 \times 3$, sendo os fatores 3 recipientes $(R 1=72$, $\mathrm{R} 2=128$ e $\mathrm{R} 3=200$ células de poliestireno) e 3 substratos ( $\mathrm{S} 1=$ $93 \%$ de solo $+7 \%$ de composto orgânico, $\mathrm{S} 2=86 \%$ de solo $+14 \%$ de composto orgânico e $\mathrm{S} 3=79 \%$ de solo $+21 \%$ de composto orgânico), totalizando nove tratamentos com quinze repetições, onde a plântula constituiu a repetição. A campo os nove tratamentos foram dispostos nos canteiros sob delineamento inteiramente casualizado. A bandeja de 72 células em conjunto com o substrato contendo $7 \%$ de composto orgânico propiciaram as melhores mudas de beterraba e alface. No campo as plantas provenientes dessa bandeja apresentaram os melhores resultados, independente do tipo de substrato.

Palavras-chave: Lactuca sativa, Beta vulgaris, bandejas, substratos, composto orgânico.

(Recebido para publicação em 14 de dezembro de 2010; aceito em 26 de agosto de 2011)

(Received on December 14, 2010; accepted on August 26, 2011)

$\mathrm{T}^{\mathrm{s}}$ he use of organic and inorganic substrates in the production of vegetable crops seedlings or in soilless cultivation is a widespread practice among farmers, however Trani et al. (2004) report that commercial formulations are recommended without the knowledge of their properties. Organic substrates such as wood residue, pine bark, rice husk, coconut fiber, etc. are used alone or in mixture (Carrijo et al. 2002). Nomura et al. (2008) note that the substrates, even though coming from a single type of material, require mineral supplementation to meet the nutritional needs of plants.

According to Silveira et al. (2002), in the production of seedlings, the use of regional materials, which can be easily obtained, can minimize the initial costs of production. Mixtures of $66 \%$ of sunnhemp and $33 \%$ of Napier were viable in the formation of lettuce, beetroot and tomato seedlings (Leal et al., 2007), and "húmus $+40 \%$ of vermiculite" in the formation of tomato, pepper and lettuce seedlings (Diniz et al., 2006).

Guimarães et al. (2002) note that the production of vegetable seedlings is one of the most important stages of the production system, which directly influences the final performance of plants in production beds. Franco \&
Prado (2008) report that the quality of seedlings can ensure the homogeneity of culture and an early harvest.

Beetroot culture has been established by direct seeding, however, the farms are irregular in function of poor germination, resulting in decreased productivity. Unlike other tuberous vegetables, beetroot adapts well to transplant, being viable the seedlings production stage in trays, making it an alternative, due to the advantages that the method provides (Guimarães et al., 2002).

The production systems of lettuce seedlings use polystyrene trays with 72 , 128, 200 and 288 cells (Marques et al., 
2003; Trani et al., 2004), environment protected (Callegari et al., 2001) and substrates (Smiderle et al., 2001; Trani et al., 2004; Diniz et al., 2006; Lopes et al., 2007; Souza et al., 2008; Lima et al., 2007; Medeiros et al., 2007; Mattos \& Liberalino Filho, 2007), trying to provide the best conditions for seedlings and to get the highest potential yield of the same. Polystyrene trays of 128 cells and 200 cells are more viable for the formation of lettuce seedlings (Marques et al., 2003), however in São Paulo, among the nursery gardeners, trays with 200 and 288 cells stand out, with which they seek to take advantage from the greenhouses spaces and the substrates saving (Trani et al., 2004).

Traditionally, the economy of the State of Mato Grosso do Sul is grounded in the view of agribusiness, with activities that occupy large tracts of land, as the beef cattle, the annual cultures of summer (soy) and winter (corn) and, recently, with government incentives, biofuel crops like sugar cane and planted forests. In this scenario, rapid-cycle crops that occupy small areas of cultivation, such as vegetable crops, were relegated to a second position. This fact causes the demand for these products to be met by imports from other states, especially São Paulo and Paraná. However, in recent years, it has been much discussed, in the state, agro-ecological zoning policies to encourage crop diversification, and the vegetable crops, specifically, started to be incorporated in the production scenario. Yet, little is known about the behavior of these species grown in the ambient conditions of the State of Mato Grosso do Sul, specifically in the Cerrado Pantanal (Cerrado Swamp) interface.

In the upper region of Pantanal of Mato Grosso do Sul, the direct sowing of beetroot has provided nonuniform beds, and, consequently, low productivity. In this region, the consumption of lettuce is high, like in other Brazilian regions, but production is still incipient, being necessary its importation. Coupled with insufficient production, it has been verified that lettuce seedlings, from 200 cells trays, have unsatisfactory development when transplanted into the field, probably due to the high temperatures characteristic of the region.

This study aimed to evaluate different sizes of containers and different substrates in the production of seedlings and field production of beetroots and lettuce in Aquidauana-MS.

\section{MATERIAL AND METHODS}

The work was conducted at the University of Mato Grosso do Sul experimental area, University of Aquidauana Unit $\left(20^{\circ} 45^{\prime} \mathrm{S}, 55^{\circ} 67^{\prime} \mathrm{W}\right.$, altitude of $174 \mathrm{~m}$ ), in the period from April to August, 2008. According to Köppen, the climate belongs to the Aw type (tropical humid), with average annual rainfall of $1,200 \mathrm{~mm}$ and $29^{\circ} \mathrm{C}$ of temperature.

In the production step of beetroot (Beta vulgaris, cv Top Tall Early Wonder) and lettuce (Lactuca sativa, cv Veneranda) seedlings, the experiment was conducted in a farm nursery of galvanized steel structure, with $8.0 \mathrm{~m}$ wide by $18.0 \mathrm{~m}$ long and $3.5 \mathrm{~m}$ high for its dimensions, closed with a net in 45 degrees, using monofilament black screen, mesh for $50 \%$ of shade. A completely randomized experimental design, in a $3 \times 3$ factorial scheme was used, where the factors were: 3 containers $[\mathrm{R} 1=$ expanded polystyrene tray with 72 cells $\left(121.2 \mathrm{~cm}^{3}\right), \mathrm{R} 2=$ expanded polystyrene tray with 128 cells $\left(34.6 \mathrm{~cm}^{3}\right)$ and $\mathrm{R} 3=$ expanded polystyrene tray with 200 cells $(22.3$ $\left.\mathrm{cm}^{3}\right)$ ]; and 3 substrates ( $\mathrm{S} 1=93 \%$ of soil $+7 \%$ of organic compost, $\mathrm{S} 2=$ $86 \%$ of soil $+14 \%$ of organic compost and $\mathrm{S} 3=79 \%$ of soil $+21 \%$ of organic compost), a total of nine treatments with 15 replications, where the seedling was a replication.

A soil layer from 10 to $40 \mathrm{~cm}$ depth of an Ultisol soil was used, collected in the area of University Aquidauana Unit, and mixed with compost manufactured by Organoeste, called Organosuper ${ }^{\circledR}$, in the preparation of the substrates to compose the three kinds of substrates. Doses of $2.5 \mathrm{~kg}$ superphosphate, $0.3 \mathrm{~kg}$ of potassium chloride and $1.5 \mathrm{~kg}$ of lime were applied to the substrates, at each $\mathrm{m}^{3}$. The various substrates were placed in the trays, carrying out the sowing of the beetroot and lettuce.

The soil and substrates composition were $(\mathrm{pH}=$ potential hydrogen ion in $\mathrm{CaCl}_{2} ; \mathrm{MO}=$ organic material in $\% ; \mathrm{K}=$ potassium in $\mathrm{cmol}_{\mathrm{c}} \mathrm{dm}^{-3} ; \mathrm{Ca}=$ calcium in $\mathrm{cmol}_{\mathrm{c}} \mathrm{dm}^{-3} ; \mathrm{Mg}=$ magnesium in $\mathrm{cmol}_{\mathrm{c}}$ $\mathrm{dm}^{-3} ; \mathrm{H}+\mathrm{Al}=$ potential acidity in $\mathrm{cmol}_{\mathrm{c}}$ $\mathrm{dm}^{-3} ; \mathrm{SB}=$ sum of bases in $\mathrm{cmol}_{\mathrm{c}} \mathrm{dm}^{-3}$; $\mathrm{T}=$ cation exchange capacity in $\mathrm{cmol}_{\mathrm{c}}$ $\mathrm{dm}^{-3} ; \mathrm{V}=$ saturation by bases in $\left.\%\right)$ : soil (5.4; $1.4 ; 0.35 ; 0.9 ; 0.8 ; 3.3 ; 2.05 ; 5.35$; 38.32). S1 (6.0; 3.2; 0.64; 2.3; 1.5; 3.0; $4.44 ; 7.44 ; 59.68) . \mathrm{S} 2(6.4 ; 3.7 ; 0.94$; $3.2 ; 1.9 ; 2.7 ; 6.04 ; 8.74 ; 69.11)$ and S3 $(6.5 ; 4.7 ; 1.53 ; 3.3 ; 2.4 ; 2.2 ; 7.23$; $9.43 ; 76.67$ ) (Source: Laboratory of soil analysis of the animal and plant health protection state agency of Mato Grosso do Sul).

At thirty-three days after sowing in trays (DAS), seedlings of both species were collected, measuring the fresh mass of aerials (MFA) and root system (MFR). Subsequently, the collected material was placed in a forced circulation oven at $65^{\circ} \mathrm{C}$ for 72 hours to obtain the dry mass of aerials (MSA) and root (RDM).

The seedlings of both species were transplanted to field plots using a completely randomized design with 15 replicates and 135 plants per plot for beetroot, and 75 for lettuce. For the lettuce crop, a spacing of $25 \times 25 \mathrm{~cm}$ was adopted, and for beetroot $15 \times 15$ $\mathrm{cm}$. The analysis of the soil in the $0-20$ $\mathrm{cm}$ layer, from the implantation cultures site, revealed the non-need for additional fertilizer in transplanting (water $\mathrm{pH}$ $1: 2.5=6.1 ; \mathrm{P}=56.6 \mathrm{mg} \mathrm{dm}^{-3} ; \mathrm{K}=0.48$ $\mathrm{cmol}_{\mathrm{c}} \mathrm{dm}^{-3} ; \mathrm{Ca}=5.4 \mathrm{cmol}_{\mathrm{c}} \mathrm{dm}^{-3} ; \mathrm{Mg}=$ $2.3 \mathrm{cmol}_{\mathrm{c}} \mathrm{dm}^{-3}$; sum of bases $(\mathrm{SB})=8.18$ $\mathrm{cmol}_{\mathrm{c}} \mathrm{dm}^{-3}$; cation exchange capacity $(\mathrm{CTC})=11.48 \mathrm{cmol}_{\mathrm{c}} \mathrm{dm}^{-3}$ and saturation by bases $=71.25 \%$ ).

Passed 38 days after transplantation in the beds (DAT), the lettuce was harvested, assessing the number of leaves of the plant (NFP), leaf area (AFP), fresh aerial mass (MFP) and dry aerial mass (MSP). The beetroot was harvested at 108 DAT with only the evaluation of fresh mass of tuberous roots (MFT).

The data were subjected to analysis of variance and the means by Tukey test 
at $5 \%$ probability, using the software Estat (1994).

\section{RESULTS AND DISCUSSION}

\section{Beetroot}

The fresh and dry mass of the root system had higher values in the S1 substrate, which did not differ from substrate S2 for trays of 72 and 200 cells. The highest fresh and dried root masses were found in the 72 cells tray, and S2 substrate showed that this container had dry mass similar to the 200 cells tray, and in the substrate S3 to the other two trays (Table 1).

Evaluating the beetroot seedling aerial part, it was found that the substrates presented virtually no differences in cultivation containers, except the 200 cells tray where it was observed that the substrate with $21 \%$ organic compost resulted in higher dry matter accumulation than the substrate with $7 \%$ (Table 1). In all substrates, the 72 cells tray promoted a greater accumulation of dry and fresh aerial mass (Table 1), evidencing the results of Marques et al. (2003), where trays with cells of greater volume form better seedlings.

The results presented in the trays with larger cells (R1 and R2) are in accordance with the comments of
Oliveira et al. (1993), in respect of the seeds surrounded by a larger amount of substrate, which showed better germination and development, also evidencing the comments of Cunha et al. (2006).

The 128 cells tray propitiated MFR of $0.226 \mathrm{~g}$ and MSR of $0.013 \mathrm{~g}$ to the substrate with $7 \%$ of organic compost, while the 200 cells tray promoted MFR of $0.177 \mathrm{~g}$ and MSR of $0.010 \mathrm{~g}$, showing that the 128 cells tray promoted biomass additions of $27.6 \%$ and $30 \%$, compared to the 200 cells tray. Echer et al. (2007) found roots with root dry mass of $0.03 \mathrm{~g}$ in seedlings from the 200 cells tray, and $0.05 \mathrm{~g}$ in seedlings from the 128 cells trays, showing an increase in biomass of $60 \%$, reporting the positive effect of the accumulation of seedling biomass formed in cells with greater volume.

In this experiment, the 72 cells tray promoted the best seedling than the 128 and 200 cells trays, however, Guimarães et al. (2002) found no differences between seedlings from the trays of 128 , 200 and 288 cells.

Probably, the low values obtained in the 200 cells container are due to faster depletion of nutrients and the limitation of space for root growth. Loureiro et al. (2006) found MSR of $0.021 \mathrm{~g}$ in the 200 cells trays 30 days after sowing in commercial compost, a higher result than that found in this experiment in three containers R1, R2 and R3 (0.019, 0.013 and $0.010 \mathrm{~g}$ ). Horta et al. (2001), evaluating the trays of 128,200 and 288 cells, found that the 288 cells tray was the worst container. In the 128 cells trays, the authors obtained an aerial dry mass of $0.02 \mathrm{~g}$ and, in the 200 cells, it was $0.012 \mathrm{~g}$, lower results than those found in this experiment, which were $0.027 \mathrm{~g}$ and $0.018 \mathrm{~g}$, respectively, for the substrate with $7 \%$ of organic compound.

Castro et al. (2003), using organic compounds (napier grass + cattle manure or poultry litter) found aerial dry mass of $2.8 \mathrm{~g}$, yet in this experiment it was $0.057 \mathrm{~g}$ for $\mathrm{S} 1$, being the organic compound proposed by the authors efficient for the production of beetroot seedlings in polystyrene trays.

In the field production, the treatments from the 72 cells tray (R1S1, R1S2 and R1S3) were similar to the treatment from the 128 cells tray and substrate with $7 \%$ of compost (R2S1), and they presented greater mass of roots (Table 3). These results show that well-formed plants respond better to field, with higher productivity. Doing an extrapolation, using the spacing of $15.0 \times 15.0 \mathrm{~cm}$, three rows, $40 \mathrm{~cm}$ of spacing between beds and, for two side harborings ( 111 beds of $0.45 \mathrm{~m}$ wide $\mathrm{x}$

Table 1. Fresh mass of root system (MFR), dry mass of root system (MSR), aerial fresh mass (MFA) and aerial dry mass (MSA) of the beetroot seedlings evaluated at 33 DAS, for containers (R) and for substrates (S) (massa fresca do sistema radicular (MFR), massa seca do sistema radicular (MSR), massa fresca da parte aérea (MFA) e massa seca da parte aérea (MSA) das mudas de beterraba avaliadas aos 33 DAS, para os recipientes (R) e para os substratos (S)). Aquidauana, UEMS, 2008.

\begin{tabular}{|c|c|c|c|c|c|c|}
\hline \multicolumn{4}{|c|}{ Fresh mass of root system (g) } & \multicolumn{3}{|c|}{ Dry mass of root system (g) } \\
\hline$\left({ }^{(* *)}\right.$ & R1 & R2 & $\mathbf{R 3}$ & R1 & R2 & R3 \\
\hline $\mathrm{S} 1$ & $0.325 \mathrm{Aa}^{(*)}$ & $0.226 \mathrm{Ab}$ & $0.177 \quad \mathrm{Ab}$ & $0.019 \mathrm{Aa}$ & $0.013 \mathrm{Ab}$ & $0.010 \mathrm{Ab}$ \\
\hline $\mathrm{S} 2$ & $0.253 \mathrm{ABa}$ & $0.134 \mathrm{Bb}$ & $0.146 \mathrm{ABb}$ & $0.015 \mathrm{ABa}$ & $0.010 \mathrm{Bb}$ & $0.011 \mathrm{Aab}$ \\
\hline S3 & $0.217 \mathrm{Ba}$ & $0.092 \mathrm{Bb}$ & $0.112 \mathrm{Bb}$ & $0.010 \mathrm{Ba}$ & $0.009 \mathrm{Ba}$ & $0.007 \mathrm{Ba}$ \\
\hline \multicolumn{4}{|c|}{ Aerial fresh mass ( $\mathrm{g}$ ) } & \multicolumn{3}{|c|}{ Aerial dry mass (g) } \\
\hline & R1 & R2 & $\mathbf{R 3}$ & R1 & $\mathbf{R 2}$ & R3 \\
\hline S1 & $0.927 \mathrm{Aa}$ & $0.358 \mathrm{Ab}$ & $0.169 \mathrm{BC}$ & $0.057 \mathrm{Aa}$ & $0.027 \mathrm{Ab}$ & $0.018 \mathrm{Bb}$ \\
\hline S2 & $0.928 \mathrm{Aa}$ & $0.319 \mathrm{Ab}$ & $0.230 \mathrm{Ab}$ & $0.065 \mathrm{Aa}$ & $0.026 \mathrm{Ab}$ & $0.019 \mathrm{ABb}$ \\
\hline S3 & $0.867 \mathrm{Aa}$ & $0.362 \mathrm{Ab}$ & $0.270 \mathrm{Ab}$ & $0.058 \mathrm{Aa}$ & $0.025 \mathrm{Ab}$ & $0.023 \mathrm{Ab}$ \\
\hline
\end{tabular}

*Same upper-case letters in columns and same lower-case letters in the rows indicate no differentiation by Tukey's test at $5 \%$ of probability (letras iguais maiúsculas nas colunas e minúsculas nas linhas dentro de cada caráter não diferem entre si pelo teste de Tukey a 5\% de probabilidade); $* * \mathrm{R} 1=72$ cells tray, $\mathrm{R} 2=128$ cells tray; $\mathrm{R} 3=200$ cells tray; $\mathrm{S} 1=93 \%$ of soil $+7 \%$ of organic compost; $\mathrm{S} 2=86 \%$ of soil $+14 \%$ of organic compost; $\mathrm{S} 3=79 \%$ of soil $+21 \%$ of organic compost $(\mathrm{R} 1=$ bandeja de 72 células; R2 = bandeja de 128 células; R3 = bandeja de 200 células; S1=93\% de solo $+7 \%$ de composto orgânico; S2= $86 \%$ de solo + $14 \%$ de composto orgânico; S3=79 \% de solo $+21 \%$ de composto orgânico). 
Table 2. Fresh mass of root system (MFR), dry mass of root system (MSR), aerial fresh mass (MFA) and aerial dry mass (MSA) of lettuce seedlings evaluated at 33 DAS, for containers (R) and substrates (S) (massa fresca do sistema radicular (MFR), massa seca do sistema radicular (MSR), massa fresca da parte aérea (MFA) e massa seca da parte aérea (MSA) das mudas de alface avaliadas aos 33 DAS, para os recipientes (R) e para os substratos (S)). Aquidauana, UEMS, 2008.

\begin{tabular}{|c|c|c|c|c|c|c|}
\hline \multicolumn{4}{|c|}{ Fresh mass of root system $(\mathrm{g})$} & \multicolumn{3}{|c|}{ Dry mass of root system (g) } \\
\hline${ }^{(* *)}$ & S1 & S2 & S3 & S1 & S2 & S3 \\
\hline $\mathrm{R} 1$ & $0.285 \mathrm{Aa}^{(*)}$ & $0.259 \mathrm{Aa}$ & $0.113 \mathrm{Ab}$ & $0.018 \mathrm{Aa}$ & $0.014 \mathrm{Aa}$ & $0.009 \mathrm{Ab}$ \\
\hline R2 & $0.157 \mathrm{Bb}$ & $0.246 \mathrm{Aa}$ & 0.099 Ac & $0.008 \mathrm{Bb}$ & $0.013 \mathrm{Aa}$ & $0.009 \mathrm{Ab}$ \\
\hline R3 & $0.155 \mathrm{Ba}$ & $0.161 \mathrm{Ba}$ & $0.119 \mathrm{Aa}$ & $0.009 \mathrm{Bb}$ & $0.013 \mathrm{Aa}$ & $0.008 \mathrm{Ab}$ \\
\hline \multicolumn{4}{|c|}{ Aerial fresh mass (g) } & \multicolumn{3}{|c|}{ Aerial dry mass (g) } \\
\hline $\mathrm{R} 1$ & 0.492 Аа & $0.166 \mathrm{Ab}$ & $0.140 \mathrm{Ab}$ & $0.039 \mathrm{Aa}$ & $0.021 \mathrm{Ab}$ & $0.015 \mathrm{Ab}$ \\
\hline $\mathrm{R} 2$ & $0.392 \mathrm{Aa}$ & $0.165 \mathrm{Ab}$ & $0.141 \mathrm{Ab}$ & $0.031 \mathrm{Aa}$ & $0.021 \mathrm{Ab}$ & $0.014 \mathrm{Ac}$ \\
\hline R3 & $0.419 \mathrm{Aa}$ & $0.172 \mathrm{Ab}$ & $0.143 \mathrm{Ab}$ & $0.031 \mathrm{Aa}$ & $0.021 \mathrm{Ab}$ & $0.014 \mathrm{Ac}$ \\
\hline
\end{tabular}

*Same upper-case letters in columns and same lower-case letters in the rows indicate no differentiation by Tukey's test at $5 \%$ of probability (letras iguais maiúsculas nas colunas e minúsculas nas linhas dentro de cada caráter não diferem entre si pelo teste de Tukey a 5\% de probabilidade); $* * \mathrm{R} 1=72$ cells tray, $\mathrm{R} 2=128$ cells tray; $\mathrm{R} 3=200$ cells tray; $\mathrm{S} 1=93 \%$ of soil $+7 \%$ of organic compost; $\mathrm{S} 2=86 \%$ of soil $+14 \%$ of organic compost; S3 $=79 \%$ of soil $+21 \%$ of organic compost $(\mathrm{R} 1=$ bandeja de 72 células; R2 = bandeja de 128 células; R3 = bandeja de 200 células; S1= 93\% de solo $+7 \%$ de composto orgânico; S2= 86 \% de solo + 14 \% de composto orgânico; S3=79 \% de solo $+21 \%$ de composto orgânico).

Table 3. Fresh mass of tuberous roots of beetroots (MFT) evaluated at 108 DAT and number of leaves (NFP), leaf area (AFP), aerial fresh mass (MFP) and aerial dry mass (MSP) of lettuce adult plants evaluated at 38 DAT, from nine treatments of seedlings (massas frescas das raízes tuberosas da beterraba (MFT) avaliadas aos 108 DAT e número de folhas da planta adulta (NFP), área foliar da planta adulta (AFP), massa fresca da parte aérea da planta adulta (MFP) e massa seca da parte área da planta adulta (MSP) de alface, avaliadas aos 38 DAT, oriundas dos nove tratamentos de mudas). Aquidauana, UEMS, 2008.

\begin{tabular}{|c|c|c|c|c|c|c|c|c|c|c|}
\hline \multirow{2}{*}{$\frac{\text { Treatment }}{\mathrm{R} 1 \mathrm{~S} 1^{(* *)}}$} & \multicolumn{2}{|c|}{ MFT (g) } & \multicolumn{2}{|l|}{ NFP } & \multicolumn{2}{|c|}{$\operatorname{AFP}\left(\mathrm{cm}^{2}\right)$} & \multicolumn{2}{|c|}{ MFP (g) } & \multicolumn{2}{|c|}{ MSP (g) } \\
\hline & 135.25 & $\mathrm{~A}^{(*)}$ & 21.70 & $\mathrm{~A}^{(*)}$ & 183.30 & $\mathrm{AB}$ & 314.80 & A & 33.20 & $\mathrm{~A}$ \\
\hline $\mathrm{R} 1 \mathrm{~S} 2$ & 130.50 & A & 21.80 & A & 220.07 & A & 326.00 & A & 28.80 & $\mathrm{AB}$ \\
\hline R1S3 & 134.00 & A & 17.30 & $\mathrm{AB}$ & 152.33 & $\mathrm{BC}$ & 214.80 & B & 24.60 & $\mathrm{BC}$ \\
\hline $\mathrm{R} 2 \mathrm{~S} 1$ & 111.25 & $\mathrm{AB}$ & 15.20 & B & 150.20 & $\mathrm{BC}$ & 148.20 & $\mathrm{BCD}$ & 23.40 & $\mathrm{C}$ \\
\hline $\mathrm{R} 2 \mathrm{~S} 2$ & 102.25 & B & 13.80 & B & 143.10 & $\mathrm{C}$ & 110.20 & $\mathrm{D}$ & 21.20 & $\mathrm{C}$ \\
\hline $\mathrm{R} 2 \mathrm{~S} 3$ & 98.75 & B & 14.70 & B & 160.14 & $\mathrm{BC}$ & 156.60 & $\mathrm{BCD}$ & 23.70 & $\mathrm{C}$ \\
\hline R3S1 & 49.50 & $\mathrm{C}$ & 15.30 & B & 136.60 & $\mathrm{C}$ & 131.80 & $\mathrm{CD}$ & 23.10 & $\mathrm{C}$ \\
\hline R3S2 & 38.00 & $\mathrm{C}$ & 16.30 & B & 164.55 & $\mathrm{BC}$ & 191.40 & $\mathrm{BC}$ & 25.30 & $\mathrm{BC}$ \\
\hline R3S3 & 47.75 & $\mathrm{C}$ & 15.00 & $\mathrm{~B}$ & 156.88 & $\mathrm{BC}$ & 152.00 & $\mathrm{BCD}$ & 22.70 & $\mathrm{C}$ \\
\hline$\overline{C V}(\%)$ & & 12 & 20 & & & .9 & 28 & .7 & 14 & .0 \\
\hline
\end{tabular}

* Same uppercase letters in columns indicate no differentiation by Tukey's test at 5\% of probability (letras iguais maiúsculas nas colunas não diferem entre si pelo teste de Tukey a 5\% de probabilidade); ${ }^{*} \mathrm{R} 1=72$ cells tray, R2=128 cells tray; R3=200 cells tray; S1=93\% of soil $+7 \%$ of organic compost; S2 $=86 \%$ of soil $+14 \%$ of organic compost; $\mathrm{S} 3=79 \%$ of soil $+21 \%$ of organic compost. (R1= bandeja de 72 células; R2 = bandeja de 128 células; R3 = bandeja de 200 células; S1 $=93 \%$ de solo $+7 \%$ de composto orgânico; S2= $86 \%$ de solo + 14 \% de composto orgânico; S3=79 \% de solo + $21 \%$ de composto orgânico).

99.2 m length in an hectare, a total of 220,224 plants), the 72 cells tray would produce $29.3 \mathrm{t} \mathrm{ha}^{-1}$ on average and the 128 and 200 cells trays would produce $22.9 \mathrm{t} \mathrm{ha}^{-1}$ and $9.9 \mathrm{tha}^{-1}$, respectively.

In a spacing of $15 \times 15 \mathrm{~cm}$, Gribogi $\&$ Salles (2007) obtained a productivity of $16.2 \mathrm{t} \mathrm{ha}^{-1}$ for seedlings made in the Plantmax ${ }^{\circledR} \mathrm{HA}$ substrate, and $17.0 \mathrm{t} \mathrm{ha}^{-1}$ for seedlings made in the Terra Fértil ${ }^{\circledR}$ HA substrate, both in 128 cells trays.
Comparing the previous extrapolation, we verified that the yields were lower than those obtained from the seedlings from 72 and 128 cells trays. Guimarães et al. (2002) affirmed that the method of production of beetroot seedlings (direct seeding and trays) did not influence productivity, but increased the production cycle for the seedlings from trays.

The method of production of beetroot seedlings using trays is promising for the region of Aquidauana because local producers can not obtain uniformity in beds with direct seeding. In the field, there was influence in the container volume used in the formation of seedlings, but the substrates did not interfere with productivity. The conditions offered by the largest volume cell tray secured better results, probably because it has suitable conditions for 
root development and increased water storage.

\section{Lettuce}

The 72 cells tray showed higher dry matter accumulation regardless of the type of substrate. The substrate of larger volume provided the best conditions for seedlings, and the cells probably retained more moisture and space for root development, therefore the seedling showed a higher vigor. Modolo \& Tessarioli Neto (1999) verified that okra seedlings produced in trays with greater volume of cell showed the best development outcomes.

The 72 cells tray promoted greater fresh and dry mass of the root system with $\mathrm{S} 1$ substrate. For $\mathrm{S} 2$ substrate, this container did not differ from R2 for MFR. The substrates with lower percentages of organic compounds (7 and 14\%) provided better root development (Table 2). The higher percentage of organic compound (S3), possibly, promoted larger pores, facilitating the process of drying out, reducing the hydraulic conductivity and reducing the contact between the substrate and the roots, hence increasing the resistance to water absorption and promoting smaller seedlings (Kramer \& Boyer, 1995). Another aspect that can be taken into consideration from this substrate (S3) is the larger amount of organic matter, which would increase the $\mathrm{C} / \mathrm{N}$ ratio (carbon/nitrogen) immobilizing nitrogen (Sampaio et al., 2008) and that would require more biological stabilization time, according to Boff et al. (2005).

Lima et al. (2007), studying the production of lettuce seedlings in the 72 cells tray combined with the texture of mixed organic compost of $4 \mathrm{~mm}$, obtained mean from the root fresh mass of $0.70 \mathrm{~g}$, while in this experiment $0.285 \mathrm{~g}$ were obtained when using the substrate with $7 \%$ of organic compost. In lettuce seedlings, Marques et al. (2003) found better seedlings in trays with greater volume of cell, in accordance with the results observed in Aquidauana (Table 2).

Leal et al. (2007), working with lettuce seedlings using substrate based on organic composts, in the mixture of $33 \%$ of napier and $66 \%$ of sunnhemp, verified MFA of $0.603 \mathrm{~g}$ and MSA of $0.053 \mathrm{~g}$, at 33 DAS, higher values compared to those found in this experiment. Substrate based on húmus and $40 \%$ of vermiculite, compared to Plantmax ${ }^{\circledR}$ commercial substrate in the production of lettuce seedlings in 128 cells trays, promoted seedlings with MFA of $0.1731 \mathrm{~g}$ and MSA of $0.068 \mathrm{~g}$ for Lucy Brow cultivar, and values of $0.1123 \mathrm{~g}$ and $0.046 \mathrm{~g}$ for Vera cultivar, higher values compared to those found in this experiment (Diniz et al., 2006).

Lettuce, tomatoes, and cauliflower seedlings on substrates from urban waste, in comparison with Plantmax ${ }^{\circledR}$, were studied by Luz et al. (2004), verifying that Plantmax ${ }^{\circledR}$ promoted the best lettuce seedlings, with $0.1525 \mathrm{~g}$ of MFA, MSA of $0.097 \mathrm{~g}$, MFR of 0.1525 $\mathrm{g}$ and MSR of $0.038 \mathrm{~g}$. On different substrates for the production of lettuce seedlings, Veronica cultivar, in 200 cells trays, Matias et al. (1999) pointed out that the organic matter and phenolic foam substrates are recommended for hydroponics, and organic matter had the greatest fresh mass of seedlings $(0.460$ $\mathrm{g} / 4$ plants), a lower result than that observed in this experiment, both for the three trays, as for the three substrates.

Results of the aerial dry mass obtained in this experiment were higher than those reported by Medeiros et al. (2007) using Fertamim fertilizer (0.052 g) and organic compound (0.072 g). In the production of lettuce seedlings with the use of a substrate prepared with earthworm coprolites, at 28 days after transplanting, Souza et al. (2008) found aerial dry mass $(0.11 \mathrm{~g})$ with $20 \%$ of the coprolites in the volumetric composition of the substrate and root dry mass $(0.04$ g) without concentration of coprolites in the composition of the substrate volume, lower values than those obtained in Aquidauana.

Lopes et al. (2007) evaluated three commercial substrates for the growth of lettuce seedlings, and concluded that Plantmax ${ }^{\circledR}$ showed the best results, where the height obtained was of 7.68 $\mathrm{cm}$, number of leaves of 5.59, dry mass of $0.885 \mathrm{~g}$, specific leaf area of 44.75 $\mathrm{dm}^{2} \mathrm{~g}^{-1}$, absolute growth rate of $0.081 \mathrm{~g}$ day $^{-1}$ and net assimilation rate of 0.035 $\mathrm{g} \mathrm{dm}^{2}$ day $^{-1}$, at 35 DAS.
Smiderle et al. (2001) obtained average mass of dry matter of six lettuce seedlings, at 21 and 40 days after sowing, of $0.95 \mathrm{~g}$ and $5.15 \mathrm{~g}$, and roots of $0.45 \mathrm{~g}$ and $3.32 \mathrm{~g}$. Andriolo et al. (2003) evaluated the growth and development of lettuce plants at different physiological ages, and concluded that the number of seedlings with 5 leaves, on average, and aerial dry mass of $0.5 \mathrm{~g} /$ seedling are suitable for transplantation. Trani et al. (2004) evaluated the height, number of leaves, clods stability and leaf area for the production of lettuce seedlings in different trays and commercial substrates, and concluded that Plantmax ${ }^{\circledR}$ provided the best results at 15 and 20 days after emergence. The 200 cells trays were better than the 288 ones.

In the field, the plants from the 72 cells trays, especially those produced on substrates with a lower percentage of organic compound (R1S1 and R1S2), promoted larger plants with greater dry matter accumulation (Table 3). Again, as observed for the beetroot, plants from containers with greater volume performed better in the field, probably because they are from more vigorous seedlings. Modolo et al. (2001) found that okra plants originated from greater volume containers produced more fruit.

Again, as observed for beetroot, the 72 cells tray, with greater volume of cell, led to larger plants. Probably, in addition to store more water content, it had greater room for development of a denser and more numerous root system, promoting better adaptability to the field.

Different trays were evaluated on production of lettuce seedlings and later production in field by Marques et al. (2003), at 28 DAS, obtaining $8.10 \mathrm{~cm}$ for the seedlings roots and $14.4 \mathrm{~cm}$ for the field, with seedlings from the 128 cells tray. In the field, the seedlings did not have room restriction for root system growth, which resulted in higher lengths. After harvesting, 30 days after transplanting, they had MFP of $146.4 \mathrm{~g}$ and MSP of $16.80 \mathrm{~g}$ for the plants from the 200 cells tray, and 124.4 $\mathrm{g}$ and $14.03 \mathrm{~g}$ for the plants from 128 cells tray. These results were lower than those obtained in Aquidauana. 
Possibly the cultivars, location and the substrate have provided larger plants in this experiment.

Silva et al. (2008) report that, for the characteristic of aerial fresh mass (MFP), organic substrates based on húmus (716.33 g), rabbit manure $(720.66 \mathrm{~g})$ and swine manure (768.33 g) were most recommended, but for the characteristics of leaves (43.73) and lettuce head diameter $(46 \mathrm{~cm})$, substrates did not differ. These results were higher than those found in Aquidauana.

Ferraz Júnior et al. (2003) analyzed the lettuce (Babá de Verão) fertilization with sewage sludge, chicken manure, NPK, NPK + sewage sludge and NPK + chicken manure, compared with a control where the soil received only liming, and verified that NPK, compared to control, did not affect the production; however, the applications of brewery sludge and chicken manure provided similar products, and with similar chemical fertilizer, to the fertilized aerial fresh mass with malt sludge (160 g plant $^{-1}$ ), 28 days after transplanting (DAS), with lower results than the ones obtained in the 72 cells trays from this study, showing the superiority of the 128 cells trays.

The growth of lettuce in the húmus + natural rice hulls; Plantmax Folhosas ${ }^{\circledR}$; húmus; carbonized rice hulls and peat was evaluated by Caron et al. (2004), studying the aerial fresh and dry mass and leaf area at two growing seasons, winter and spring, and concluded that the humus substrate gave the highest fresh mass for the two growing seasons (324 g/plant in winter; $315 \mathrm{~g} / \mathrm{plant}$ in spring), greater dry mass (14.0 g/ plant in winter; $9.78 \mathrm{~g} /$ plant in spring) and greater leaf area $\left(0.92 \mathrm{~m}^{2} /\right.$ plant in winter; $0.63 \mathrm{~m}^{2} /$ plant in spring), featuring fresh mass similar to those obtained in Aquidauana in the 72 cells trays, and less dry mass.

In studies on the effect of doses of mineral and organic fertilizers on the lettuce culture, Pasqualetto et al. (1998) found, for the organic fertilization, aerial fresh mass of $350.35 \mathrm{~g} / \mathrm{plant}$ and dry mass of $14.12 \mathrm{~g} / \mathrm{plant}$, and for the mineral fertilization, respectively, $363.18 \mathrm{~g} /$ plant and $15.07 \mathrm{~g} / \mathrm{plant}, 70$ days after emergence; these results being superior to the ones obtained in Aquidauana, in growth and production of 3 cultivars of lettuce, in environment protected and field.

In the growth and development of lettuce conducted in plastic greenhouse with fertigation on substrates, in two seasons (autumn and winter), Medeiros et al. (2001) verified that the number of leaves (22.5), aerial fresh mass (297.1 $\mathrm{g} / \mathrm{plant}$ ) and aerial dry mass (10.54 $\mathrm{g} /$ plant) were superior in autumn, at 43 DAT. The results found for the parameters of aerial fresh and dry mass were lower than those found in this experiment.

Under the conditions that the experiments were developed, the 72 cells tray was the best container in the seedling production of beetroot, of which the substrate with $7 \%$ of commercial organic compost promoted more root mass. In the field, the plants from this tray had more tuberous roots, regardless of the type of substrate. For lettuce, in the stage of seedling production, the 72 cells tray promoted greater fresh and dry mass of aerial, which was similar to the 128 cells tray for the root mass. At this stage, the substrate with $7 \%$ of organic compost had more root mass. For the field production phase, plants from the 72 cells tray, especially with the substrates of $7 \%$ and $14 \%$ of organic compost, promoted greater leaf area, fresh and dry mass of aerials.

\section{ACKNOWLEDGEMENTS}

The authors thank the Dean of Research and Postgraduate Studies (PROPP), University of Mato Grosso do Sul (UEMS), for the resources for research support, granted to projects of Scientific Initiation, making possible the execution of this work.

\section{REFERENCES}

ANDRIOLO JL; ESPINDOLA MCG; STEFANELLO MO. 2003. Crescimento e desenvolvimento de plantas de alface provenientes de mudas com diferentes idades fisiológicas. Ciência Rural 33: 35-40.

BOFF P; DEBARBA JF; SILVA E; WERNER H. 2005. Qualidade e sanidade de mudas de cebola em função da adição de composto termófilo. Horticultura Brasileira 23: 875-
880. Disponível em www.scielo.br/pdf/hb/ v23n4/a03v23n4.pdf. Acessado em 15 de setembro de 2008 .

CALLEGARI O; SANTOS HS; SCAPIM CA. 2001. Variações do ambiente e práticas culturais na formação de mudas e na produtividade da alface. Acta Scientiarum. Agronomy 23: 1117-1122.

CARON BO; POMMER SF; SCHMIDT D; MANFRON PA; MEDEIROS SLP. 2004. Crescimento da alface em diferentes substratos. Revista de Ciências Agroveterinárias 3: 97-104.

CARRIJO OA; LIZ RS; MAKISHIMA N. 2002. Fibra da casca do coco verde como substrato agrícola. Horticultura Brasileira 20: 533-535.

CASTRO CM; RIBEIRO RLD; ALMEIDA DL. 2003. Caracterização e avaliação de substratos orgânicos para produção de mudas de beterraba. Agronomia 37: 19-24.

CUNHA AM; CUNHA GM; SARMENTO RA; CUNHA GM; AMARAL JFT. 2006. Efeito de diferentes substratos sobre o desenvolvimento de mudas de Acacia sp. Revista Árvore 30: 207-214.

DINIZ KA; GUIMARÃES STMR; LUZ JMQ. 2006. Húmus com substrato para a produção de mudas de tomate, pimentão e alface. Bioscience 22: 63-70.

ECHER MM; GUIMARÃES VF; ARANDA AN; BORTOLAZZO ED; BRAGA JS. 2007. Avaliação de mudas de beterraba em função do substrato e do tipo de bandeja. Semina: Ciências agrárias 28: 45-50.

ESTAT. 1994. Sistema para análises estatísticas (v. 2.0). Jaboticabal: Departamento de Ciências Exatas, FCAV-UNESP.

FERRAZ JUNIOR ASL; SOUZA SR; CASTRO SRP; PEREIRA RB. 2003. Adubação de alface com lodo de esgoto de cervejaria. Horticultura Brasileira 21: 60-63.

FRANCO CF; PRADO RM. 2008. Nutrição de micronutrientes em mudas de goiabeira em resposta ao uso de soluções nutritivas. Acta Scientiarum. Agronomy 30: 403-408.

GRIBOGI CC; SALLES RFM. 2007. Vantagens da semeadura direta no cultivo de beterraba. Revista Acadêmica 5: 33-38.

GUIMARÃES VF; ECHER MM; MINAMI K. 2002. Métodos de produção de mudas, distribuição de matéria seca e produtividade de plantas de beterraba. Horticultura Brasileira 20: 505-509.

HORTA ACS; SANTOS HS; SCAPIM CA; CALLEGARI O. 2001. Relação entre produção de beterraba, Beta vulgaris var. conditiva, e diferentes métodos de plantio. Acta Scientiarum 23: 1123-1129.

KRAMER PJ; BOYER JS. 1995. Water relations of plants and soils. San Diego: Academic Press $1995.495 \mathrm{p}$

LEAL MAA; GUERRA JGM; PEIXOTO RTG; ALMEIDA DL. 2007. Utilização de compostos orgânicos como substratos na produção de mudas de hortaliças. Horticultura Brasileira 25: 392-395.

LIMA GKL; LIBERALINO FILHO L; LINHARES PCF; MARACAJÁ PB; ANDRADE WG. 2007. Produção de mudas 
de alface com composto orgânico misto de três texturas em três tipos de bandejas. Caatinga 20: $160-166$.

LOPES JLW; BOARO CSF; PERES MR; GUIMARÃES VF. 2007. Crescimento de mudas de alface em diferentes substratos. Revista Biotemas 20: 19-25.

LOUREIRO DC; AQUINO AM; DE-POLLI H; LEAL MAA; CARMO MV. 2006. Produção de mudas de beterraba e alface com residuos orgânicos domésticos. Seropédica: UFFRRJ. 4p. (Comunicado técnico).

LUZ JMQ; BRANDÃO FD; MARTINS ST; MELO B. 2004. Produtividade de cultivares de alface em função de mudas produzidas em diferentes substratos comerciais. Bioscience Journal 20: 61-65.

MARQUES PAA; BALDOTTO PV; SANTOS ACP; OLIVEIRA L. 2003. Qualidade de mudas de alface formadas em bandejas de isopor com diferentes números de células. Horticultura Brasileira 21: 649-651.

MATIAS GCS; COMETTI NN; GÓMEZ GP; ROCHA JDS. 1999. Avaliação de substratos comerciais para a produção de mudas de alface. Horticultura Brasileira 17: 159-162.

MATTOS JCO; LIBERALINO FILHO J. 2007. Composto orgânico misto na formação de mudas de alface. Revista Verde 2: 105-112.

MEDEIROS DC; LIMA BAB; BARBOSA MR; ANJOS RSB; BORGES RD; CAVALCANTE NETO JG; MARQUES LF. 2007. Produção de mudas de alface com biofertilizantes e substratos. Horticultura Brasileira 25: 433436.

MEDEIROS LAM; MANFRON PA; MEDEIROS SLP; BONNECARRÈRE RG. 2001. Crescimento e desenvolvimento da alface (Lactuca sativa L.) conduzida em estufa plástica com fertirrigação em substratos. Ciência Rural 31: 199-204.

MODOLO VA; TESSARIOLI NETO J. 1999. Desenvolvimento de mudas de quiabeiro [Abelmoschus esculentus (L.) Moench] em diferentes tipos de bandeja e substrato. Scientia Agricola 56: 377-381.

MODOLO VA.; TESSARIOLI NETO J; ORTIGOZZA LER. 2001. Produção de frutos de quiabeiro a partir de mudas produzidas em diferentes tipos de bandejas e substratos. Horticultura Brasileira 19: 39-42.

NOMURA ES; LIMA JD; GARCIA VA; RODRIGUES DS. 2008. Crescimento de mudas micropropagadas da bananeira cv. Nanicão, em diferentes substratos e fontes de fertilizantes. Acta Scientiarum 30: 359-363.

OLIVEIRA RP; SCIVITTARO WB; VASCONCELLOS LABC. 1993. Avaliação de mudas de maracujazeiro em função do substrato e do tipo de bandeja. Scientia Agricola 50: 261-266.

PASQUALETTO A; SOARES CB; AZEVEDO WR. 1998. Efeito de doses de adubos mineral e orgânico sobre características agronômicas da alface (Lactuca sativa L.). Pesquisa Agropecuária Tropical 28: 47-53.

SAMPAIO RA; RAMOS SJ; GUILHERME DO; COSTA CA; FERNANDES LA. 2008. Produção de mudas de tomateiro em substratos contendo fibra de coco e pó de rocha. Horticultura Brasileira 26: 499-503.

SILVA EA; MENDONÇA V; TOSTA MS; OLIVEIRA AC; REIS LL; BARDIVIESSO DM. 2008. Germinação da semente e produção de mudas de cultivares de alface em diferentes substratos. Semina 29: 245-254.

SILVEIRA EB; RODRIGUES VJLB; GOMES AMA; MARIANO RLR; MESQUITA JCP. 2002. Pó de coco como substrato para produção de mudas de tomateiro. Horticultura Brasileira 20: 211-216.

SMIDERLE OJ; SALIBE AB; HAYASHI AH; MINAMI K. 2001. Produção de mudas de alface, pepino e pimentão em substratos combinando areia, solo e plantmax. Horticultura Brasileira 19: 253-257.

SOUZA SR; FONTINELE YR; SALDANHA CS; ARAÚJO NETO SE; KUSDRA JF. 2008. Produção de mudas de alface com o uso de substrato preparado com coprólitos de minhoca. Ciência e Agrotecnologia 32: 115-121.

TRANI PE; NOVO MCSS; CAVALLARO JÚNIOR ML; TELLES LMG. 2004. Produção de mudas de alface em bandejas e substratos comerciais. Horticultura Brasileira 22: 290294. 